\title{
Child career development: present and future trends
}

\author{
Mark Watson' ${ }^{1} \cdot$ Laura Nota $^{2} \cdot$ Mary McMahon $^{3}$
}

Published online: 3 June 2015

(C) Springer Science+Business Media Dordrecht 2015

There has been an understanding for centuries that the foundations of adolescent and adult development lie in childhood. Thus, the seventeenth century poet, John Milton, stated (in the gender restricted language of those times) that "childhood shows the man, as morning shows the day" (Milton, 1671, lines 220-221 in Kerrigan, Rumrich, \& Fallon, 2007). The discipline of career psychology has long recognised the importance of childhood in lifespan career development. Indeed, the more recent theoretical development of life design argues that "factors central to life design, such as career exploration, career awareness, occupational aspirations, and expectations, vocational interests, and career adaptability begin during the childhood years" (Hartung, 2015, p. 90).

The theoretical recognition of career development beginning in childhood has not resulted, however, in a substantive and cohesive body of literature. True, the last decade has produced several reviews and a book, but a search of PsycINFO for the years 1995-2015 using the keywords of career development and children reveals the limited emphasis on this lifespan stage. For instance, while there have been 2662 articles on career development between 1995 and 2005, only 88 articles (representing three percent of the total) have specifically focused on children. In the following decade from 2006 to date only 124 articles (again representing three percent of the total) out of 3879 articles on career development focused on children.

Mark Watson

mark.watson@nmmu.ac.za

1 Faculty of Health Sciences, Nelson Mandela Metropolitan University, Port Elizabeth, South Africa

2 Department of Philosophy, Sociology, Education and Applied Psychology, University of Padova, Padua, Italy

3 School of Education, The University of Queensland, Brisbane, QLD, Australia 
The percentage of articles on child career development over the last two decades has remained, thus, at the same low level. There is a need to take stock of how the field has qualitatively, rather than quantitatively, progressed, as well as what the field needs to consider in terms of future directions. Several themes have emerged from the broader literature on child development, for instance, that emphasise the contextual nature of development and the reciprocal influence of individuals and the environments in which they develop.

This special issue was conceptualised against the background that the extant literature on child career development has consistently remained "fragmented, disparate and lacking in theory, research, practice and policy" (Watson, Nota, \& McMahon, 2014, p. 248). It seems timely thus to consider recent developments in child career development theory, research, practice and policy in order to better understand and provide guidance to child career development. In order to focus potential contributions to this special issue on these topics, four themes in child career development were identified: advances in theory; innovations in practice and assessment; research in diverse settings; and policy implications.

\section{Content of the special issue}

The six articles of this special issue represent co-authored teams spanning six countries and five nations. Ferrari, Ginevra, Santilli, Nota, Sgaramella, and Soresi examine the predictive role of career exploration on Italian children's perceptions and actual knowledge of occupations. Their study reports on differences across Holland's typological categories as well as for gender. Howard, Flanagan, Castine and Walsh examine American children's understanding of factors influencing their future career choices. Their results suggest that older children identify influences that are either more specific or categorical, or that dynamically interact. Lee and Porfeli's article tests a model of socialisation to work in a family context on American parent-youth dyads and the implications of this model for school engagement. Amongst other findings, the authors establish that positive perceptions of work lead to greater emotional and cognitive engagement with school work.

Liu, McMahon, and Watson consider the specific context of family in the development of mainland Chinese children's career aspirations. These authors identify three superordinate themes about the nature of parental influence on children's career aspirations. Oliveira, Taveira, and Porfeli propose that greater consideration needs to be given to the role of emotions in child career development. These authors consider the relationship between emotion, behaviour, functioning and learning in child career development. In the final article of this special issue, Watson, Nota, and McMahon consider the preceding five articles both in relation to the four themes identified in the original call for papers as well as the present contexts within which child career development occurs. This article concludes by proposing seven directions for future research in child career development. Although the literature on child career development remains limited, the articles in this special issue attest to the strong foundation that is being built and the progress that is being made to advance the field. 


\section{References}

Hartung, P. J. (2015). Life design in childhood: Antecedents and advancement. In L. Nota \& J. Rossier (Eds.), Handbook of life design: From practice to theory and from theory to practice (pp. 89-102). Göttingen, Germany: Hogrefe.

Kerrigan, W., Rumrich, J., \& Fallon, S. M. (Eds.). (2007). The complete poetry and essential prose of John Milton. New York, NY: Modern Library.

Watson, M., Nota, L., \& McMahon, M. (2014). Call for papers: Special issue on childhood career development. International Journal for Educational and Vocational Guidance, 14, 248-249. 